\title{
Human Cytokine Response to ex vivo Amyloid- $\beta$ Stimulation is Mediated by Genetic Factors
}

\author{
Danielle Posthuma,' Ingrid Meulenbelt, ${ }^{2}$ Anton J. M. de Craen, ${ }^{3}$ Eco J. C. de Geus,' P. Eline Slagboom, ${ }^{2}$ \\ Dorret I. Boomsma,' and Rudi G. J. Westendorp ${ }^{3}$ \\ ' Department of Biological Psychology, Vrije Universiteit Amsterdam, the Netherlands \\ ${ }^{2}$ Department of Medical Statistics, Leiden University Medical Center, the Netherlands \\ ${ }^{3}$ Department of General Internal Medicine, Leiden University Medical Center, the Netherlands
}

\begin{abstract}
Thention hrough its ability to induce the enhanced release and production of cytokines, amyloid- $\beta$ is responsible for the chronic inflammatory response that contributes to Alzheimer's disease (AD). Determining whether the response of monocytes to amyloid- $\beta$ stimulation is under genetic control may help understand the basis of why some people are more prone to develop neuronal degeneration than others. In the current study we investigated the heritability of the cytokine (IL-10, IL-6, IL-1 $\beta$, IL-1ra, TNF- $\alpha$ ) production capacity upon ex vivo stimulation with amyloid- $\beta$ in whole blood samples of 222 twins and 85 singleton siblings from 139 extended twin families. It was found that individual differences in amyloid- $\beta$ induced cytokine production capacity are to a large extent of genetic origin, with heritability estimates ranging from $55 \%$ (IL-1 $\beta$ ) to $68 \%$ (IL-6). We conclude that genes influencing amyloid- $\beta$-induced cytokine response may provide clues to the progression of $A D$ pathology.
\end{abstract}

Senile plaques constitute the key pathological feature of Alzheimer's disease (AD) and are composed of insoluble amyloid- $\beta(\mathrm{A} \beta)$, activated microglia, astrocytes, and degenerating neurons. The accumulation of inflammatory microglia at sites of $\mathrm{A} \beta$ deposition significantly contributes to neuronal degeneration (McGeer $\&$ McGeer, 1995). A $\beta$ is able to initiate the accumulation and activation of microglia by triggering the complement cascade and induce enhanced release and production of cytokines (Bornemann et al., 2001; Shen $\&$ Meri, 2003). A $\beta$, itself, may induce a chronic inflammatory response contributing to both further plaque development and neuronal degeneration, detectable in reactive microglia within senile plaques.

In twins, the concordance with diagnosed $\mathrm{AD}$ (up to death) has been found to be two- to threefold greater for monozygotic (MZ) than for dizygotic (DZ) pairs, indicating strong genetic influences on the presence of AD (Gatz et al., 1997). Also the age of onset of $\mathrm{AD}$ has been shown to be under genetic influence (Pedersen at al., 2001). The inflammatory response to the presence of $A \beta$ in the brain could underly this heritable component in $\mathrm{AD}$. In the current twin study we therefore investigated whether production capacity of cytokines upon stimulation with $\mathrm{A} \beta$ is a heritable characteristic.

Microglia are derived from monocytic lineage and arrive in the central nervous system (CNS) late in embryonic development. Based on their lineages and phenotype, microglial cells are generally accepted as the macrophages of the CNS (Davis et al., 1992). Hence, peripheral monocytes may be a useful model to mimic the effects of $A \beta$ peptides on human microglia function in the brain. To determine the magnitude of the heritability of the production capacity of cytokines upon stimulation with $A \beta$, we examined in a sample of $\mathrm{MZ}$ and $\mathrm{DZ}$ twin pairs and their siblings the cytokine profiles upon ex vivo stimulation of whole blood samples with lipopolysaccharide (LPS) and A $\beta$. This design allows the determination of the extent to which interindividual differences in $A \beta$-stimulated cytokine production capacity can be ascribed to genetic differences between individuals. MZ twins share all, or nearly all (Martin et al., 1997), of their genetic material. DZ twins and siblings share on average $50 \%$ of their segregating genes. If resemblances (often expressed as correlations) in $\mathrm{MZ}$ pairs are larger than in $\mathrm{DZ}$ pairs, this is a first indication that genetic influences are of importance (Martin et al., 1997; Posthuma et al., 2004). The use of the so-called 'extended' twin design (including twins and their siblings) ensures relative high statistical power to detect sources of nongenetic, environmental variation that are shared by family members (Posthuma \& Boomsma, 2000).

\footnotetext{
Received 26 January, 2005; accepted 2 February, 2005.
}

Address for correspondence: Danielle Posthuma, Vrije Universiteit, Department of Biological Psychology, van der Boechorststraat 1, 1081 BT Amsterdam, the Netherlands.E-mail:danielle@psy.vu.nl 
Previously we have shown that individual differences in the cytokine production capacity of peripheral monocytes upon lipopolysaccharide (LPS) stimulation can be explained by genetic variation (de Craen et al., 2005; Westendorp et al., 1997). Here we examine whether such is also the case when cells are stimulated by both LPS and A $\beta$.

\section{Subjects and Methods Subjects and Procedure}

This study is part of a larger study on the genetics of adult brain function (Posthuma et al., 2001). Twins and their siblings were invited for an additional visit to the lab for blood extraction. Three hundred and seven twins and their siblings from 139 families participated. The age range was 15.6 to 68.7 years (mean age $=38.7$, $S D=12.5$ ). Forty-six per cent were males, and $54 \%$ were females. The total sample included $41 \mathrm{MZ}$ pairs, $52 \mathrm{DZ}$ pairs, and one family consisting of trizygotic triplets. In addition, 85 siblings participated and 33 single twins (who participated with a nontwin sibling). Zygosity of same-sex twins was determined by typing highly polymorphic genetic markers. Fasting blood samples were drawn in the morning before $11.00 \mathrm{am}$. All subjects gave informed consent and received a breakfast after donating their blood sample. The study was approved by the Medical Ethical Committee of the Vrije Universtiy Amsterdam. All participants provided written informed consent.

\section{Cytokine Production Capacity}

Cytokine production capacity was assessed with an $e x$ vivo whole blood assay, as described previously with small alterations (de Craen et al., in press; van der Linden et al., 1998). In short, heparinized whole blood samples were first diluted fivefold with RPMI1640 (Gibco Life technologies). Then, samples were stimulated with either $10 \mathrm{ng} / \mathrm{ml}$ LPS (from Escherichia coli 0111, Difco Laboratories) alone or $10 \mathrm{ng} / \mathrm{ml}$ LPS in combination with $50 \mathrm{U} / \mathrm{ml} \mathrm{Ab} \mathrm{1-42} \mathrm{fibrils} \mathrm{(Bachem)}$ and incubated for 24 hours at $37^{\circ} \mathrm{C}$ with $5 \% \mathrm{CO}_{2}$. The amyloid was fibrilar as shown by green birefringence in a polarizing microscope after Congo red staining. After centrifugation, the supernatants were stored at $-80^{\circ} \mathrm{C}$ until assaying for Interleukin- $1 \beta$ (IL1及), Interleukin-1ra (IL-1ra), Interleukin-6 (IL-6), Interleukin-10 (IL-10), and Tumor Necrosis Factor- $\alpha$ (TNF- $\alpha$ ), using standard ELISA techniques according to the manufacturers' guidelines (Central Laboratory of the Blood Transfusion Service, Amsterdam, the Netherlands).

Stimulation of unactivated monocytes with $A \beta$ does not result in enhanced cytokine release. However, $\mathrm{A} \beta$ induces increased release of cytokines from LPSactivated human monocytes (Lorton et al., 1996). Therefore, to assess the individual $A \beta$-induced cytokine response the level of cytokine production upon LPS alone was subtracted from production upon LPS plus $A \beta$ stimulation.

\section{Statistical Analysis}

Five subjects were excluded from the analyses: the determination of the cytokine profile failed due to technical problems in 2 subjects, and 3 subjects had TNF- $\alpha$ concentrations of more than $100 \mathrm{pg} / \mathrm{ml}$ under unstimulated conditions. The distribution of each cytokine was inspected for outliers, which were subsequently eliminated from the analyses ( 3 outliers for IL-1 $\beta, 2$ for IL- 6 , and 1 for TNF- $\alpha$ ). We tested for heterogeneity across zygosity and sex with respect to means and variances. In addition, the effect of age on the observed cytokine production scores was included as a covariate.

\section{Genetic Analyses}

The data were first summarized into correlations for $\mathrm{MZ}$ and DZ twin and sibling pairs. Next, the variation in cytokine response upon $A \beta$ stimulation was decomposed into additive genetic variation $(\mathrm{A})$, shared environmental variation $(\mathrm{C})$ or nonshared environmental variation (E; Boomsma et al., 2002; Posthuma et al., 2004). Shared environmental variation by definition included all environmental sources of variation that twins and siblings from the same family share, while nonshared environmental variation refers to the environmental variation that is unique for an individual and that is typically not shared with other family members. For DZ twin and sibpairs similarity in shared environmental influences is $100 \%$ and similarity of additive genetic influences is $50 \%$. There was by definition no similarity in nonshared environmental influences. For MZ twin pairs similarities of additive genetic and shared environmental influences were fixed at $100 \%$. Thus, the expectation for the total variance is $\mathrm{A}+\mathrm{C}+\mathrm{E}$, the expectation for the covariance between $\mathrm{MZ}$ twins is $\mathrm{A}+\mathrm{C}$, and the expectation for DZ twins/sibpairs is $1 / 2 \mathrm{~A}+\mathrm{C}$. Heritability is calculated as the proportional contribution of genetic variation to the total observed variation. All analyses were carried out using the statistical software package Mx (Neale, 1997). Estimation of parameters was obtained by normal theory maximum likelihood. Testing of the significance of $\mathrm{A}$ and $\mathrm{C}$ was done by constraining them at zero and comparing the resulting fit of the model using likelihood ratio tests (Neale \& Cardon, 1992).

\section{$\overline{\text { Results }}$}

The distributions of $\mathrm{A} \beta$ induced cytokine production capacity is graphically represented in Figure 1 . The distribution of the production capacity is wide, representing both up and down regulation of individual samples.

Table 1 shows significant upregulation by $\mathrm{A} \beta$ for IL$1 \beta$ and significant downregulation for IL-1ra, IL-10, IL-6, and TNF- $\alpha$. No differences in variances or means between MZ twins, DZ twins and sibling pairs were found. Also, no such differences were found between males and females except for a mean difference in IL-10 production. Men had a higher IL-10 production com- 

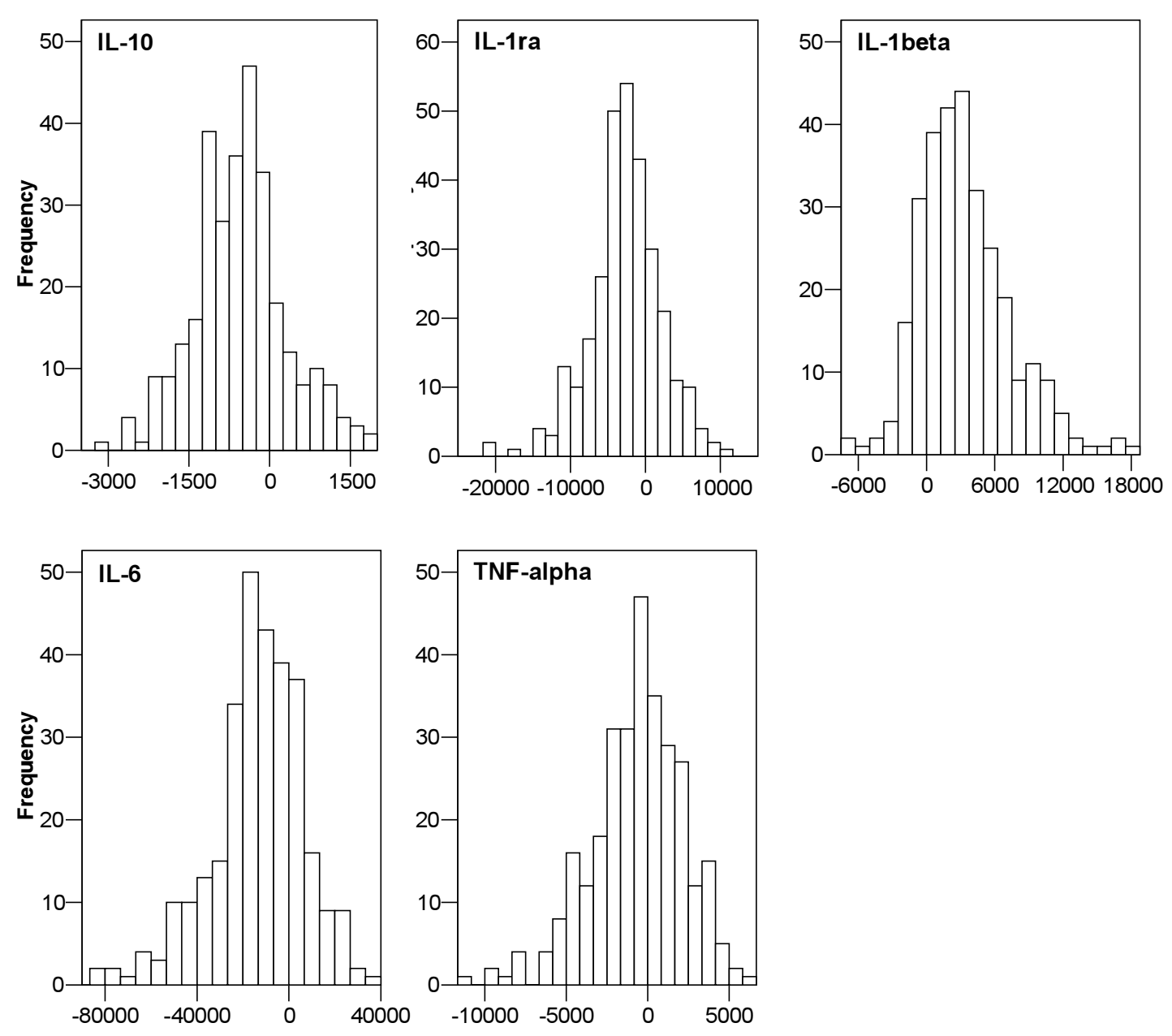

Figure 1

Histograms of the production of cytokines (in $\mathrm{pg} / \mathrm{ml}$ ) upon stimulation of $A \beta$, calculated by subtracting the cytokine level after LPS stimulation from the cytokine level after subsequent amyloid- $\beta$ stimulation.

pared to women $(+282.71 \mathrm{pg} / \mathrm{ml}$; see Table 1$)$. There was no association with age for any of the cytokines. The difference between cytokine production after LPS stimulation and cytokine production after $\mathrm{A} \beta$ stimulation was statistically different $(p<.001)$ from zero for all five cytokines.

Maximum likelihood estimates of twin and sibling correlations are given in Table 2. No differences between DZ twin correlations and sibling correlations were found. MZ correlations ranged from .36 for $A \beta$-induced regulation of TNF- $\alpha$ levels to .65 for $A \beta$-induced regulation of IL-6 levels. DZ correlations were lower than the $\mathrm{MZ}$ correlation, indicating the presence of genetic factors in the $A \beta$-induced cytokine response.

Decomposition of the variation into additive genetic, shared environmental and nonshared environmental variation indicated that variation in $A \beta$ induced regulation of IL-10, IL-1 $\beta$ and IL- 6 variation was caused by additive genetic sources and nonshared environmental sources. Heritabilities of IL-10 were estimated at $58 \%$, for IL- $1 \beta$ at $55 \%$ and for IL- 6 at $67 \%$. Genetic and shared evironmental sources of variation could not be distinguished between for IL1ra and TNF- $\alpha$, although the poor fit of the model that included only nonshared environmental sources of variation indicates that familial (i.e., genetic or shared environmental) sources are important.

\section{Table 1}

Sample Descriptives

\begin{tabular}{llrrr}
\hline & & $N$ & $\begin{array}{r}\text { Mean } \\
(\mathrm{pg} / \mathrm{ml})\end{array}$ & $S D$ \\
\hline Males & $\mathrm{A} \beta$-induced production of IL-10 & 139 & -351 & 970 \\
(Mean age & $\mathrm{A} \beta$-induced production of IL-1ra & 139 & -2497 & 4774 \\
38.29 years; & $A \beta$-induced production of II-1 $\beta$ & 135 & 2982 & 4355 \\
$S D$ 12.30) & $\mathrm{A} \beta$-induced production of IL-6 & 137 & $-14,716$ & 21,375 \\
& $\mathrm{~A} \beta$-induced production of TNF- $\alpha$ & 138 & -746 & 3002 \\
Females & $\mathrm{A} \beta$-induced production of IL-10 & 163 & -718 & 738 \\
(Mean age & $\mathrm{A} \beta$-induced production of IL-1ra & 163 & -2725 & 4810 \\
39.08 years; & $A \beta$-induced production of II-1 $\beta$ & 163 & 3639 & 3642 \\
$S D$ 12.63) & $A \beta$-induced production of IL-6 & 163 & $-13,012$ & 19,711 \\
& $A \beta$-induced production of TNF- $\alpha$ & 163 & -585 & 2702 \\
\hline
\end{tabular}

Note: Amyloid- $\beta$ production capacity was calculated by subtracting the cytokine level after LPS stimulation from the cytokine level after amyloid- $\beta$ stimulation. 
Table 2

Twin and Sibpair Correlations ( $r$ ) for A $\beta$-Induced Cytokine Production

\begin{tabular}{llllll}
\hline & $\begin{array}{l}N \\
\text { (individuals) }\end{array}$ & MZ pairs & $\begin{array}{l}\text { DZ/ } \\
\text { sibpairs }\end{array}$ & $r_{\mathrm{mz}}$ & $r_{\mathrm{dz} / \mathrm{sib}}$ \\
IL-10 & 302 & 41 & 192 & .58 & .28 \\
IL-1ra & 302 & 41 & 192 & .39 & .29 \\
II-1 $\beta$ & 298 & 40 & 186 & .55 & .27 \\
IL-6 & 300 & 41 & 189 & .65 & .39 \\
TNF- $\alpha$ & 301 & 41 & 190 & .36 & .24 \\
\hline
\end{tabular}

Note: DZ/sibpairs include all possible (nonindependent) DZ/sibpairings within a family. For example a family consisting of DZ twins and three additional siblings forms $10 \mathrm{DZ} /$ sibpairs.

In all cases, a model that included only nonshared environmental influences provided a poor fit to the data, as indicated by a significant $p$-value in the $\mathrm{E}$ model (Table 3).

\section{Discussion}

The effects of $A \beta$ on additional cytokine release from ex vivo LPS-stimulated whole blood samples show large individual differences. These differences were found to be of genetic origin to a large extent, with heritability estimates ranging from $55 \%$ (IL-1 $\beta$ ) to $68 \%$ (IL-6). This implies that monocytes and possibly also microglia have an innate cytokine response to the presence of $A \beta$. In other words, the chronic inflammatory

\section{Table 3}

Fit results from models where the variance of $A \beta$-induced cytokine production is decomposed into additive genetic variance $(A)$, shared environmental variance $(C)$ and nonshared environmental variance $(E)$.

\begin{tabular}{lllclll}
\hline & Tested & Versus & $p$-value & $\%$ A & $\%$ C & $\%$ E \\
\hline IL-10 & ACE & Null & .48 & 58 & 0 & 42 \\
& AE & ACE & $\mathbf{1 . 0 0}$ & $\mathbf{5 8}$ & - & $\mathbf{4 2}$ \\
& CE & ACE & .02 & & & \\
& E & AE & .00 & & & \\
IL-1ra & ACE & Null & .65 & 21 & 19 & 60 \\
& AE & ACE & .30 & $\mathbf{4 4}$ & - & $\mathbf{5 6}$ \\
& CE & ACE &. $\mathbf{4 2}$ & - & $\mathbf{3 2}$ & $\mathbf{6 8}$ \\
& E & AE & .00 & & & \\
IL-1 3 & ACE & Null & .40 & 55 & 0 & 45 \\
& AE & ACE & $\mathbf{1 . 0 0}$ & $\mathbf{5 5}$ & - & $\mathbf{4 5}$ \\
& CE & ACE & .02 & & & \\
& E & AE & .00 & & & \\
IL-6 & ACE & Null & .65 & 52 & 13 & 35 \\
& AE & ACE &. $\mathbf{3 8}$ & $\mathbf{6 7}$ & - & $\mathbf{3 3}$ \\
& CE & ACE & .02 & & & \\
& E & AE & .00 & & & \\
TNF- $\alpha$ & ACE & Null & .22 & 25 & 11 & 64 \\
& AE & ACE & $\mathbf{. 5 4}$ & $\mathbf{4 2}$ & - & $\mathbf{5 8}$ \\
& CE & ACE &. $\mathbf{4 6}$ & - & $\mathbf{2 5}$ & $\mathbf{7 5}$ \\
& E & AE & .00 & & & \\
\hline
\end{tabular}

Note: *The ACE models were all tested against a saturated model in which the variance was not decomposed into $A, C$ and $E$ (i.e., the 'null model'). A nonsignificant $p$-value denotes a nonsignificant worsening of the fit. Best model in bold. response to the presence of $A \beta$ depends on an individual's genetic background and may thus explain why some individuals are more prone to develop reactive microglia and continue on to develop AD than others.

In the past two decades several genes related to the onset and progression of symptoms in $\mathrm{AD}$ have been identified, such as ApoE, Presenilin-1, Presenilin-2, Amyloid Precusor Protein (Corder et al., 1993; Goate et al., 1991; Levy-Lahad et al., 1995; Rogaev et al., 1995; Selkoe, 1996; Sherrington et al., 1995). Together these genes account for roughly $10 \%$ of $\mathrm{AD}$ prevalence. Futhermore, genetic variants within the IL- $1 \mathrm{a}, \quad$ IL-1 $\beta$ and IL- $1 \mathrm{rn}$ genes have been associated/related to age of onset and progression of symptoms of AD (Alvarez et al., 2002; Combarros et al., 2002; Griffin \& Mrak, 2002; Licastro et al., 2003; Sciacca et al., 2003). Possibly these variants affect the innate production capacity towards a pro-inflammatory profile.

Cytokines play critical roles in the development and progression of $\mathrm{AD}$ (Mrak et al., 1995), not only as a consequence of the disease, but also as a precursor to it. The presence of A $\beta$ stimulates microglia, astrocytes and oligodendrocytes to secrete proinflammatory cytokines, a very early step in the development of AD (Mott et al., 2004; Tan et al., 1999). Recently, we have shown that the production of cytokines in a LPSstimulated whole blood assay is under strict genetic control (De Craen et al., in press). The present study expands this evidence by showing that in healthy, non$\mathrm{AD}$ human subjects of middle age, the $\mathrm{A} \beta$-induced inflammatory response is also under genetic control.

It has been suggested that chronic inflammatory responses contribute to the development of $\mathrm{AD}$ pathology (Akiyama et al., 2000; Eikelenboom \& van Gool, 2004). Here we propose that the heritable component in the rate of $\mathrm{AD}$ progression is partly explained by the innate cytokine production capacity of monocyte-derived cells. Our results warrant further investigation of LPS/A $\beta$ responses and variation in cytokine and cytokine receptor genes in relation to $\mathrm{AD}$ age of onset and progression.

\section{Acknowledgments}

This study was carried out with financial support from the Universitair Stimulerings Fonds (grant number 96/22), the Human Frontiers Science Program (grant number rg0154/1998-B), and the Hersenstichting Nederland (8F00.06). D. Posthuma was supported by the GenomeEUtwin project (European Union Contract No. QLG2-CT-2002-01254). We thank Corine de Koning-Treurniet, Marja Kersbergenvan Oostrom, and Margot van Schie-Troost for whole blood stimulations and cytokine determinations.

\section{References}

Akiyama, H., Barger, S., Barnum, S., Bradt, B., Bauer, J., Cole, G. M., Cooper, N. R., Eikelenboom, P., Emmerling, M., Fiebich, B. L., Finch, C. E., Frautschy, 
S., Griffin, W. S., Hampel, H., Hull, M., Landreth, G., Lue, L., Mrak, R., Mackenzie, I. R., McGeer, P. L., O’Banion, M. K., Pachter, J., Pasinetti, G., PlataSalaman, C., Rogers, J., Rydel, R., Shen, Y., Streit, W., Strohmeyer, R., Tooyoma, I., Van Muiswinkel, F. L., Veerhuis, R., Walker, D., Webster, S., Wegrzyniak, B., Wenk, G., \& Wyss-Coray, T. (2000). Inflammation and Alzheimer's disease. Neurobiology of Aging, 1, 383-421.

Alvarez, V., Mata, I. F., Gonzalez, P., Lahoz, C. H., Martinez, C., Pena, J., Guisasola, L. M., \& Coto, E. (2002). Association between the TNFalpha-308 A/G polymorphism and the onset-age of Alzheimer disease. American Journal of Medical Genetics, 14, 574-577.

Boomsma, D., Busjahn, A., \& Peltonen, L. (2002). Classical twin studies and beyond. Nature Reviews Genetics, 3, 872-882.

Bornemann, K. D., Wiederhold, K. H., Pauli, C., Ermini, F., Stalder, M., Schnell, L., Sommer, B., Jucker, M., \& Staufenbiel, M. (2001). Abeta-induced inflammatory processes in microglia cells of APP23 transgenic mice. American Journal of Pathology, 158, 63-73.

Combarros, O., Sanchez-Guerra, M., Infante, J., Llorca, J., \& Berciano, J. (2002). Gene dose-dependent association of interleukin-1A [-889] allele 2 polymorphism with Alzheimer's disease. Journal of Neurology, 249, 1242-1245.

Corder, E. H., Saunders, A. M., Strittmatter, W. J., Schmechel, D. E., Gaskell, P. C., Small, G. W., Roses, A. D., Haines, J. L., \& Pericak-Vance, M. A. (1993). Gene dose of apolipoprotein E type 4 allele and the risk of Alzheimer's disease in late onset families. Science, 261, 921-923.

Davis, E. J., Foster, T. D., \& Thomas, W. E. (1994). Cellular forms and functions of brain microglia. Brain Research Bulletin, 34, 73-78.

De Craen, A. J. M., Posthuma, D., Remarque, E. J., van den Biggelaar, A. H. J., Westendorp, R. G. J., \& Boomsma, D. I. (2005). Heritability estimates of innate immunity: An extended twin study. Genes and Immunity, 6, 167-170.

Eikelenboom, P., \& van Gool, W. A. (2004). Neuroinflammatory perspectives on the two faces of Alzheimer's disease. Journal of Neural Transmisssion, 111, 281-294.

Gatz, M., Pedersen, N. L., Berg, S., Johansson, B., Johansson, K., Mortimer, J. A., Posner, S. F., Viitanen, M., Winblad, B., \& Ahlbom, A. (1997). Heritability for Alzheimer's disease: The study of dementia in Swedish twins. The Journals of Gerontology. Series A, Biological Sciences and Medical Sciences, 52, M117-M125.

Goate, A., Chartier-Harlin, M. C., Mullan, M., Brown, J., Crawford, F., Fidani, L., Giuffra, L., Haynes, A., Irving, N., \& James, L. (1991). Segregation of a missense mutation in the amyloid precursor protein gene with familial Alzheimer's disease. Nature, 349, 704-706.
Griffin, W. S., \& Mrak, R. E. (2002). Interleukin-1 in the genesis and progression of and risk for development of neuronal degeneration in Alzheimer's disease. Journal of Leukocyte Biology, 72, 233-238.

Levy-Lahad, E., Wasco, W., Poorkaj, P., Romano, D. M., Oshima, J., Pettingell, W. H., Yu, C. E., Jondro, P. D., Schmidt, S. D., Wang, K., Crowley, A. C., Fu, Y. H., Guenette, S. Y., Galas, D., Nemens, E., Wijsman, E. M., Bird, T. D., Schellenberg, G. D., \& Tanzi, R. E. (1995). Candidate gene for the chromosome 1 familial Alzheimer's disease locus. Science, 269, 973-977.

Licastro, F., Grimaldi, L. M., Bonafe, M., Martina, C., Olivieri, F., Cavallone, L., Giovanietti, S., Masliah, E., \& Franceschi, C. (2003). Interleukin-6 gene alleles affect the risk of Alzheimer's disease and levels of the cytokine in blood and brain. Neurobiology of Aging, 24, 921-926.

Lorton, D., Kocsis, J. M., King, L., Madden, K., \& Brunden, K. R. (1996). Beta-Amyloid induces increased release of interleukin-1 beta from lipopolysaccharide-activated human monocytes. Journal of Neuroimmunology, 67, 21-29.

Martin, N. G., Boomsma, D. I., \& Machin, G. (1997). A twin pronged attack on complex traits. Nature Genetics, 17, 387-392.

McGeer, P. L., \& McGeer, E. G. (1995). The inflammatory response system of brain: Implications for therapy of Alzheimer and other neurodegenerative diseases. Brain Research Reviews, 21, 195-218.

Mott, R. T., Ait-Ghezala, G., Town, T., Mori, T., Vendrame, M., Zeng, J., Ehrhart, J., Mullan, M., \& Tan, J. (2004). Neuronal expression of CD22: Novel mechanism for inhibiting microglial proinflammatory cytokine production. Glia, 46, 369-379.

Mrak, R. E., Sheng, J. G., \& Griffin, W. S. (1995). Glial cytokines in Alzheimer's disease: Review and pathogenic implications. Human Pathology, 26, 816-823.

Neale, M. C. (1997). Mx: Statistical modeling. VCU Box 900126, Richmond VA 23298.

Neale, M. C., \& Cardon, L. R. (1992). Methodology for genetic studies of twins and families. Dordrecht, the Netherlands: Kluwer Academic.

Pedersen, N. L., Posner, S. F., \& Gatz, M. (2001). Multiple-threshold models for genetic influences on age of onset for Alzheimer disease: Findings in Swedish twins. American Journal of Medical Genetics, 105, 724-728.

Posthuma, D., Beem, A. L., de Geus, E. J. C, van Baal, G. C., von Hjelmborg, J. B., Iachine, I., \& Boomsma, D. I. (2004). Theory and practice in quantitative genetics. Twin Research, 6, 361-376.

Posthuma, D., \& Boomsma, D. I. (2000). A note on the statistical power in extended twin designs. Behavior Genetics, 30, 147-58.

Posthuma, D., Neale, M. C., Boomsma, D. I., \& de Geus, E. J. C. (2001). Heritability of alpha peak frequency 
and its relationship with IQ. Behavior Genetics, 31, 567-579.

Rogaev, E. I., Sherrington, R., Rogaeva, E.A., Levesque, G., Ikeda, M., Liang, Y., Chi, H., Lin, C., Holman, K., Tsuda, T., Mar L., Sorbi, S., Nacmias, B., Piacentini, S., Amaducci, L., Chumakov, I., Cohen, D., Lannfelt, L., Fraser, P. E., Rommens, J. M., \& St GeorgeHyslop, P. H. (1995). Familial Alzheimer's disease in kindreds with missense mutations in a gene on chromosome 1 related to the Alzheimer's disease type 3 gene. Nature, 376, 775-778.

Sciacca, F. L., Ferri, C., Licastro, F., Veglia, F., Biunno, I., Gavazzi, A., Calabrese, E., Martinelli Boneschi, F., Sorbi, S., Mariani, C., Franceschi, M., \& Grimaldi, L. M. (2003). Interleukin-1B polymorphism is associated with age at onset of Alzheimer's disease. Neurobiology of Aging, 24, 927-931.

Selkoe, D. J. (1996). Amyloid beta-protein and the genetics of Alzheimer's disease. The Journal of Biological Chemistry, 271, 18295-18298.

Shen, Y., \& Meri, S. (2003). Yin and yang: Complement activation and regulation in Alzheimer's disease. Progress in Neurobiology, 70, 463-472.

Sherrington, R., Rogaev, E. I., Liang, Y., Rogaeva, E. A., Levesque, G., Ikeda, M., Chi, H., Lin, C., Li, G., Holman, K., Tsuda, T., Mar, L., Foncin, J.-F., Bruni, A. C., Montesi, M. P., Sorbi, S., Rainero, I., Pinessi,
L., Nee, L., Chumakov, I., Pollen, D., Brookes, A., Sanseau, P., Polinsky, R. J., Wasco, W., Da Silva, H. A. R., Haines, J. L., Pericak-Vance, M. A., Tanzi, R. E., Roses, A. D., Fraser, P. E., Rommens, J. M., \& St. George-Hyslop, P. H. (1995). Cloning of a gene bearing missense mutations in early-onset familial Alzheimer's disease. Nature, 375, 754-760.

Tan, J., Town, J., Paris, D., Mori, T., Suo, Z., Crawford, F., Mattson, M. P., Flavell, R. A., \& Mullan, M. (1999). Microglial activation resulting from CD40CD40L interaction after amyloid stimulation. Science, 286, 2352-2355.

Thomas, W. E. (1992). Brain macrophages: Evaluation of microglia and their functions. Brain Research Reviews, 17, 61-74.

van der Linden, M. W., Huizinga, T. W., Stoeken, D. J., Sturk, A., \& Westendorp, R. G. (1998) Determination of tumour necrosis factor-alpha and interleukin-10 production in a whole blood stimulation system: Assessment of laboratory error and individual variation. Journal of Immunological Methods, 218, 63-71.

Westendorp, R. G., Langermans, J. A., Huizinga, T. W., Elouali, A. H.,Verweij, C. L., Boomsma, D. I., \& Vandenbroucke, J. P. (1997). Genetic influence on cytokine production and fatal meningococcal disease. Lancet, 349, 170-173. 